\title{
Harbiye (Daphne) Şelalesi Mesire Alanının rekreasyonel potansiyelinin belirlenmesi
}

\section{Assessment of the recreational potential of the Harbiye (Daphne) Waterfall Recreational Area}

\section{Şeyma YiĞiT}

Hatay Mustafa Kemal Üniversitesi, Mimarlık Fakültesi, Peyzaj Mimarlı̆̆ı Bölümü, Antakya, HATAY

Eser Bilgisi / Article Info

Araştırma makalesi / Research article

DOI: 10.17474/artvinofd.946558

Sorumlu yazar / Corresponding author

Şeyma YiĞiT

e-mail: seymayigit@mku.edu.tr

Geliş tarihi / Received

01.06.2021

Düzeltme tarihi / Received in revised form

25.08.2021

Kabul Tarihi / Accepted

09.09.2021

Elektronik erişim / Online available

18.11.2021

\section{Anahtar kelimeler:}

Harbiye şelalesi

Gülez yöntemi

Mesire alanları

Rekreasyonel potansiyel

\section{Keywords:}

Harbiye waterfall

Gülez method

Rezcreational areas

Recreational potential

\begin{abstract}
Özet
Kentler sosyo-kültürel ve ekonomik ihtiyaçlar başta olmak üzere pek çok açıdan ihtiyaçlara cevap vermektedir. Bu nedenle ülke nüfusunun yarısından fazlası kent ekosistemi içerisinde yaşamını sürdürmektedir. Fakat kentlerdeki artan nüfus nedeniyle yoğun ve plansız yapılaşma meydana gelmektedir. Dolayısıyla insanların rekreasyon faaliyetlerini gerçekleştirecekleri açık ve yeşil alanlar azalmaktadır. Bu durum ise insanların her geçen gün doğadan uzaklaşmasına neden olmaktadır. Fakat özellikle son yıllarda fiziksel, sosyal, psikolojik, kişisel beceri - yeteneklerin geliştirilmesi ve duygusal intiyaçların karşılanması amacıyla insanlar rekreasyon alanlarına daha fazla ihtiyaç duymaktadırlar. Bu rekreasyon alanlarından biri ise orman içi dinlenme alanları diğer ismiyle mesire alanlarıdır. Bu çalışma Hatay iline bağlı Defne ilçesi sınırları içerisinde yer alan Harbiye (Daphne) Şelalesi mesire alanının rekreasyon potansiyelinin belirlenmesini amaçlamıştır. Çalışmada "Gülez Yöntemi" uygulanmıştır. Yöntem kapsamında alanı en az bir kez ziyaret etmiş olan öğretim elemanlarına anket soruları yöneltilmiştir. Literatür taraması - anket verileri - yerinde analiz ile mesire alanının rekreasyon potansiyeli \%65 (rekreasyon potansiyeli yüksek) olarak belirlenmiştir. Fakat mesire alanının rekreasyon potansiyelini "çok yüksek" yapabilmek için insan müdahalesi ile değişebilecek "ulaşılabilirlik, rekreatif kolaylık ve olumsuz etkenler" kriterleri üzerinde durulmuştur. Bu kriterlerin rekreasyon potansiyeli üzerindeki etkisi istatistiksel açıdan incelenmiştir. Böylelikle bu kriterlerin öğeleri arasında ilişkiler saptanmış ve çalışma sonucunda mesire alanı için geliştirilen önerilerin temelini oluşturmuştur.
\end{abstract}

\begin{abstract}
Cities respond to the needs of urbanites, especially socio-cultural and economic ones. For this reason, more than half of Turkey's population has been lived in the urban ecosystem. Because of the increasing population density in cities, unplanned urbanization takes place. Therefore, open and green areas where people can perform their recreational activities are decreasing. This situation causes people to move away from nature day by day. However, especially in recent years, people need recreational areas more to develop physical, social, psychological, personal skills and abilities and to meet their emotional needs. One of these essential recreation areas is urban forests. This study aimed to determine the recreational potential of the Harbiye (Daphne) Waterfall promenade area within the boundaries of Defne district of Turkey's Hatay province. The "Gülez Method" was applied in the study. Survey questions were asked to the instructors who visited the area at least once. With the literature review, survey data and, on-site analysis, the recreation potential of the promenade area was determined as $65 \%$ (high recreational potential). However, "accessibility," "recreational convenience" and, "negative factors" criteria could be enhanced by intervention to increase the recreational potential of the promenade "high" to "very high." The effect of these criteria on the recreational potential was analyzed statistically. Thus, the relations between the factors of these criteria were determined. As a result of the study, they formed the basis of the suggestions developed for the recreation area.
\end{abstract}

\section{Giriş}

Sanayi Devrimi'nden sonra buharlı makinelerin icadı ve çalışma koşullarının iyileştirilmesiyle kırdan kente göç başlamıştır. Böylelikle kentlerdeki nüfus oranı artmış ve beraberinde yapılaşmalar da artmıştır. 21. yüzyılın gelişen teknolojisi ve değişen insan ihtiyaçları nedeniyle de yaşam alanları, yapılaşmanın oluşturduğu gri beton yığınları arasına sıkışmıştır. Bu beton yığınları arasında insanoğlu, hayatta kalabilmek ve ihtiyaçlarını karşılayabilmek için barınma, iş hayatı ve sosyal yaşam üçgeninde yaşamını sürdürmektedir. Fakat bu yaşam üçgeni gün geçtikçe doğadan uzaklaşmış ve böylece açık ve yeşil alanların sayısı da azalarak niteliklerini kaybetmeye başlamıştır. Rekreasyonel aktivitelerin gerçekleştirilmesi ve kent yaşamının sebep olduğu kargaşa ortamından sıyrılarak ruhsal dinginlik sağlanması amacıyla insanlar doğaya yeniden yönelmişlerdir. Bu yönelim ise rekreatif 
faaliyetlere hizmet eden çeşitli rekreasyon alanlarına doğru olmuştur.

Broadhurst (2001)'ın tanımına göre rekreasyon; insanların boş zamanlarında meşgul olmayı tercih ettiği, fiziksel, psikolojik ve sosyal aktiviteleri içeren çok yönlü bir etkinliktir. Hazar (2014)'ın tanımına göre ise rekreasyon; bireylerin yapmakta zorunlu olduğu davranışlar dışında kalan zaman diliminde, tamamen istekli olarak katıldığı ve doyuma ulaştığı etkinlik olarak tanımlanmıştır. Ayrıca rekreasyon; stresli ve monoton geçen günlük yaşamdan sonra, insanların severek yaptığı, beden sağlığının oluşması ile verimli bir çalışma için yapılan aktiviteler olarak tanımlanmaktadır (Aran 1967, Öztürk 2005, Surat 2016). Rekreasyon sembolik anlamlarının yanı sıra, sübjektif bir yapıdadır yani herkes için farklı bir şekilde algılanabilir (Madrigal 2006, Alkan 2020). Fakat temelde rekreasyona duyulan isteğin bazı nedenleri bulunmaktadır. Bunlar; fiziksel, sosyal, psikolojik, kişisel beceri ve yeteneklerin geliştirilmesi ve duygusal nedenlerdir. Rekreasyon alanları da bu isteklere cevap verebilmek adına planlanmış ve tasarlanmış alanlardır.

Rekreasyon alanları büyük ölçekten küçük ölçeğe doğru şu şekilde sınıflandırılabilir: Milli parklar ve koruma alanları, bölge parkları, yöre parkları ve mesire alanları, kent parkları, semt parkları, mahalle parkları, spor alanları, çocuk oyun alanları ve çocuk bahçeleri. Ülkemiz yasal mevzuatında rekreasyonel faaliyetlere izin verilen korunan alanlar milli parklar, tabiat parkları ve orman içi dinlenme alanlarıdır (Altuntaş 2020). "Orman içi dinlenme alanı", bir diğer ifadeyle mesire yeri, halkın rekreasyon ihtiyaçlarını karşılamak ve turistik faaliyetlere imkan vermek amacıyla genellikle günübirlik olarak kullanılan, gerekli tüm alt / üst yapıların tesis edildiği, estetik ve doğal değerlere sahip tabii ormanlık alanlardır (Anonim 3, Altuntaş 2020).

05.03.2013 tarihinde yayımlanan Resmi Gazete'nin 28578 sayısında Mesire Alanları Yönetmeliği'ne göre 3 tip Mesire Alanı bulunmaktadır. Bunlar:

A tipi mesire alanı: Ziyaretçi potansiyelinin yüksek olduğu, günübirlik kullanımın yanı sıra geceleme imkânları da sağlayan, çadır, karavan, motor-karavan ve kır evi, kır lokantası, kır kahvesi gibi az katlı, doğa ile uyum içerisinde olan yapı ve tesisler ile yöresel ürünlerin satıldığı satış ve sergi yeri, piknik tesisleri, çardak ile diğer rekreasyonel yapı ve tesisleri içinde bulunduran mesire alanlarıdır.

B tipi mesire alanı: Yerleşim merkezlerinin etrafında bulunan, rekreasyonel kaynakların ve ziyaretçi potansiyelinin yüksek olduğu, yalnızca günübirlik kullanım imkânı olan kır kahvesi, kır lokantası, yöresel ürünlerin satıldığı satış ve sergi yeri, piknik tesisleri, çardak ile diğer rekreasyonel yapı ve tesisleri içinde bulunduran mesire alanlarıdır.

C tipi mesire alanı: Kaynakların ve ziyaretçi potansiyelinin düşük ve orta yoğunlukta olduğu, günübirlik ihtiyaçların karşılanması amacıyla, piknik tesisleri, yöresel ürünler satış ve sergi yeri, çardak ve diğer rekreasyonel yapı ve tesisleri içinde bulunduran mesire alanlarıdır.

$A, B$ ve $C$ tipi mesire yerlerinde toplumun ve ülkenin sosyal, kültürel, ekonomik ve tarihi faydaları düşünülerek alan kullanım planlaması yapılmaktadır. Bu amaçla geliştirilen birçok yöntem bulunmaktadır. Bunlar; 1959'da Clawson'un, 1963'de Knetsch'ın, 1967' de Kiemstedt'ın, 1967 'de Knetsch ve Davis'ın, 1968 ve 1969 'da Prodan'ın, 1969 ve 1971 'de Pabs'ın, 1971'de Clavvson ve Knetsch'ın, 1971'de Ruppert'in, 1971'de Lier'in, 1973' de Buchwald ve arkadaşlarının, 1976'da Altan'ın, son olarak 1980'de Gülez'in yaptığı çalışmalardır.

Bir alanın rekreasyon potansiyelini saptarken, yöntemlerin çok azı alanın güncel rekreasyon potansiyelini vermektedir. Bir kısmı ise, bölgesel ölçekte olan büyük alanların rekreasyonel aktivitelere uygunluğunu belirlemektedir. Yöntemlerin pek çoğu ise mevcut sorunlara ekonomik açıdan yaklaşmaktadır. Ancak bu yöntemlerde, doğal peyzaj elemanlarını göz ardı etmekte ya da çok az oranda dikkate almaktadır. Herhang bir alanın rekreasyon potansiyeli belirlenirken bazı formüllere, matematiksel işlemlere gereksinim duyulmaktadır. Bir alanın güncel doğal peyzaj elemanlarını ve jeofiziksel özelliklerini dikkate alan yöntemler ise, çoğunlukla var olan olumsuz etkenleri yok saymakta veya çok az oranda dikkate almaktadır. Üstelik bu yöntemlerden çok azı orman içi rekreasyon alanları için analiz edilmiştir (Gülez 1980).

Belirtilen nedenlerden dolayı, herhangi bir orman içi rekreasyon alanında ülkemiz koşulları ve olanakları da düşünülerek, rekreasyon potansiyelinin daha kolay bir şekilde analiz edilmesini sağlayabilecek bir yöntemin gerekli olduğu sonucuna ulaşılmıştır (Gülez 1980). Bu amaç kapsamında en son geliştirilen ve halen günümüzde orman içi rekreasyon potansiyelini belirlemede sıklıkla kullanılan yöntem "Gülez Yöntemi" dir.

Bu çalışmada, Hatay ili Defne ilçesine bağı Harbiye Şelalesi B tipi mesire alanının rekreasyon potansiyelinin belirlenmesi amaçlanmıştır. Günübirlik ziyaretçi 
yoğunluğunun fazla olması, yeterli su kaynaklarının bulunması, kent içi konumu, zengin bitki örtüsü, ulaşım kolaylığı ve doğası nedeniyle seçilen çalışma alanı aynı zamanda yeniden düzenlenmesi ve planlanması gerektiği düşünülen bir alandır. Bu nedenle çalışmanın bulguları ve sunulan öneriler belirtilen mesire alanının, alan kullanım planlamasına katkı sağlayabilir.

\section{MATERYAL ve YÖNTEM}

\section{Materyal}

Çalışma alanı ülkemizin en güneyinde bulunan Hatay ilinin Defne (eski ismiyle Daphne) ilçesine bağlı Harbiye Şelalesi mesire alanıdır. Defne ilçesi Hatay’ın 15 ilçesinden biridir. ilç̧e coğrafi konum itibariyle (Şekil 1) Antakya merkez ilçesinin güneyinde yer alırken, ilçenin batısında Samandağ, güneyinde Yayladağı ve doğusunda Altınözü ilçeleri bulunmaktadır. İlçe uzun yıllar Antakya'ya bağı̆ı kalmıştır. Fakat 2012 yılında belediyeler yasası çıkmış ve Defne Antakya'dan ayrılarak ayrı bir ilçe olarak ilan edilmiştir. 2020 TÜik verilerine göre Defne ilçe nüfusu 160.066 'dır. Nüfus yoğunluğu bakımdan değerlendirildiğinden Hatay ilinin sırasıyla Antakya ve İskenderun ilçelerinden sonra 3. büyük ilçesidir.

Hatay, Akdeniz ikliminin etkisi altındadır. Dolayısıyla Defne ilçesi de sıcak ve ılıman iklim koşullarına sahiptir. İlçenin yıllık ortalama sıcaklı̆̆ı $17.3^{\circ} \mathrm{C}$ iken yıllık ortalama yağış miktarı 658 mm'dir (Anonim 1). Deniz seviyesinden 119 m yüksekte bulunan Defne ilçesinde Temmuz ayı en kurak aydır.
Defne, Antik çağın ünlü Daphne kentidir. Defne ilçe sınırlarında bulunan Harbiye Şelaleleri ise tarihi ve mitolojik önemi ile mikro klima etkisi yaratan doğal ortamı sayesinde yılın her döneminde ziyaret edilmektedir. Çalışma alanı olarak belirlenen Harbiye Şelalesi mesire alanı aktif olarak halkın kullanımına açık ve ulaşım sağlanamayan kısımları ile birlikte oldukça büyük ve engebeli bir alana sahiptir. Alanda rekreatif faaliyetler, halkın kullanımına açık yerlerde olmaktadır. Bu nedenle çalışma alanı bu kapsamda sınırlandırılmıştır. Çalışma alanı sınırları (Şekil 2) için, mesire alanının doğusunda Döver Köyü yolu, kuzeyinde Harbiye Şelalesi ana giriş yolu ve güzergâhı, güneyinde Döver Köy yolundan ayrılan patika yol ve batısında patika yol güzergâhı belirlenmiştir. Bu sınırlar dâhilinde toplam alan 60.7 ha. dır.

\section{Yöntem}

Harbiye Şelalesi mesire alanının rekreasyonel potansiyelinin belirlenmesi amacıyla, Kiemstedt (1967) ve Buchwald (1973) tarafından oluşturulan ve Gülez (1980) tarafından geliştirilen "Orman içi Rekreasyon Potansiyelinin Saptanması" yöntemi çalışma alanına uygulanmıştır. Bu yöntem kapsamında hedef kitleye yönelik anket çalışması yapılmış ve ankete verilen yanıtlar arasındaki ilişkilerin tespit edilmesi amacıyla SPSS 20 programında "Ki Kare (Chi-Square) Testi gerçekleştirilmiştir. Elde edilen verilerin sonucunda çalışma alanının mevcut rekreasyon potansiyeli belirlenmiş ve bulgular değerlendirilerek çeşitli öneriler ortaya konmuştur.

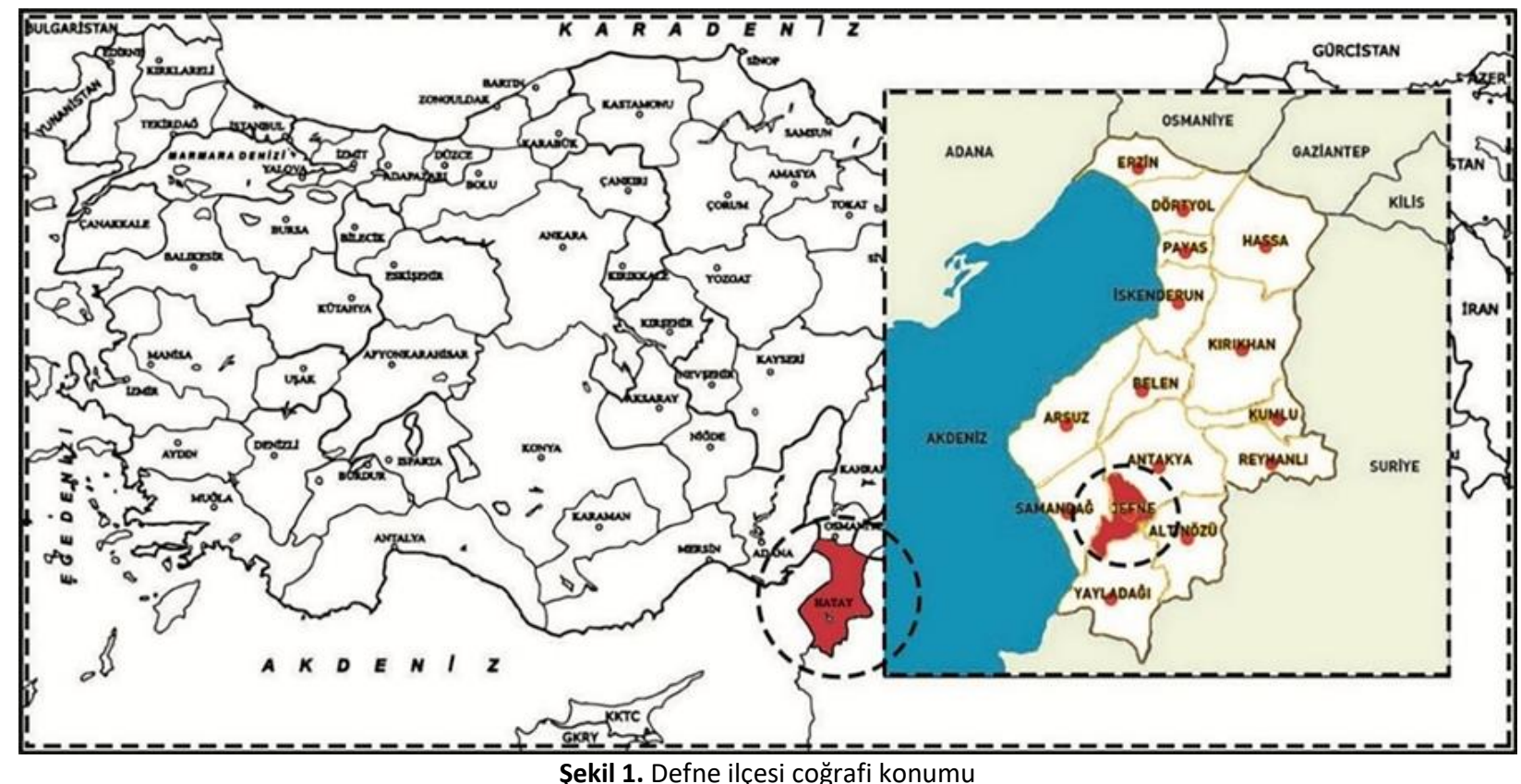




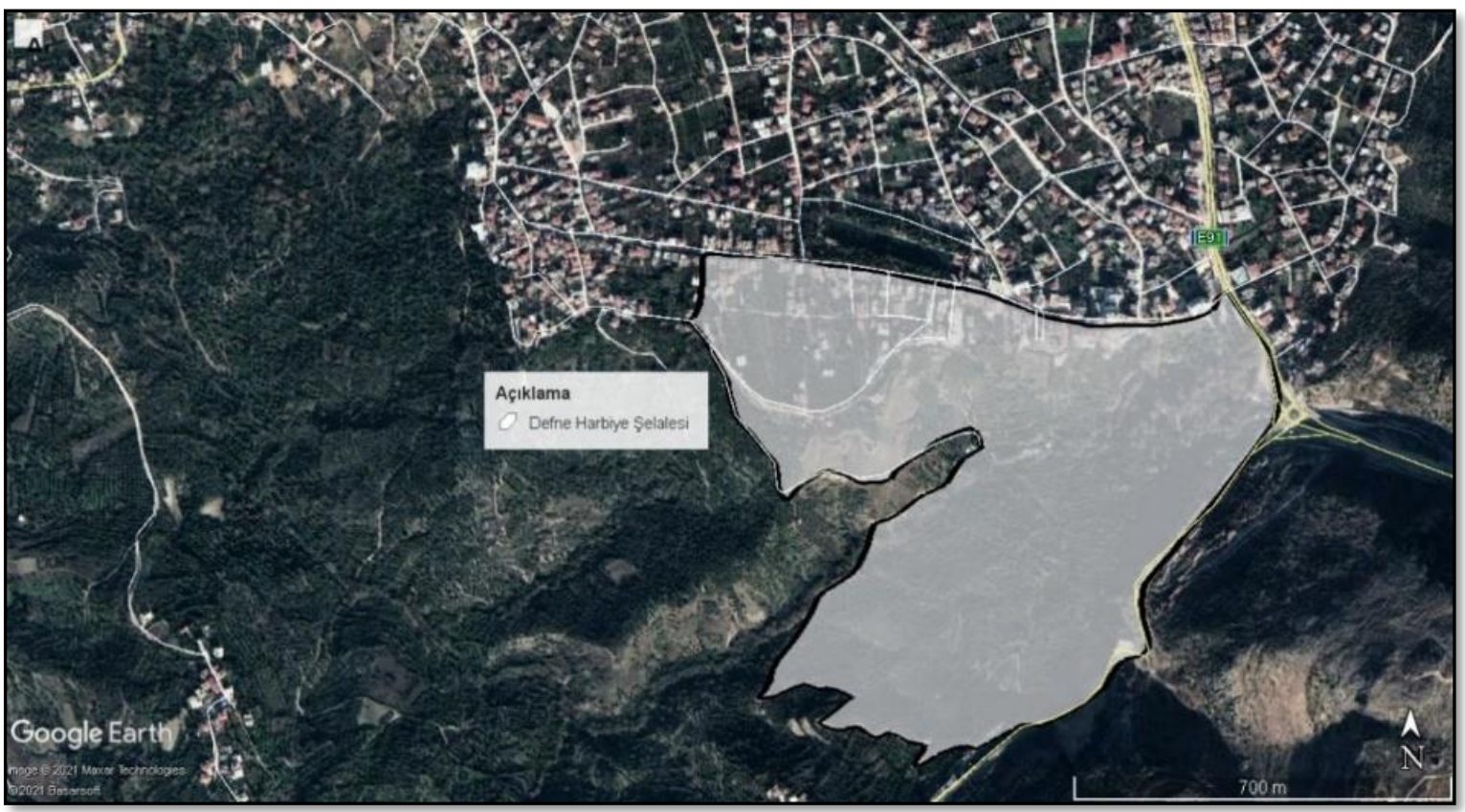

Şekil 2. Çalışma alanı konumu ve sınırları (Google Earth Pro)

\section{Anket Çalışması}

Araştırmanın yönteminde belirtilen anketler için hedef kitle olarak, daha önceden çalışma alanını en az bir defa ziyaret etmiş olan uzmanların görüşlerine ihtiyaç duyulmuştur. Bu nedenle anket çalışmasına Hatay Mustafa Kemal Üniversitesi Mimarlık Fakültesi öğretim elemanları dâhil edilmiştir. Gönüllülük esasına dayalı olan bu çalışmaya 17 uzman / akademik personel katılım sağlamıştır. Katılımcılara çalışma yöntemi ile ilgili ön bilgi verildikten sonra, elektronik ortamda sunulan anket soruları ile alanı değerlendirmeleri istenmiştir.

Gülez yöntemine göre rekreasyonel potansiyelin belirlenmesi amacıyla geliştirilen matematiksel formül aşağıda ifade edilmiştir.

$R P(\%)=P+\dot{I}+U+R K+O S E$

Yöntemdeki formülün uygulanabilmesi için kriterler, öğeler ve bu kriterlerin ağırlık puanları bulunmaktadır. Yöntemde 5 kriter vardır. Bunlar; Peyzaj değeri, İklim değeri, Ulaşılabilirlik, Rekreatif kolaylık ve Olumsuz etkenlerdir. Her kriterinde öğeleri bulunmaktadır. Kriterlerin toplam puanı ise 100 üzerinden değerlendirilmiştir. Belirtilen kriterler ve toplam ağırlık puanları Çizelge 1 'de belirtildiği gibidir.
Çizelge 1. Gülez yöntemi kriterleri ve aldıkları maksimum puanlar (Gülez, 1990)

\begin{tabular}{|c|c|c|}
\hline Kriterler & Sembol & $\begin{array}{c}\text { Maksimum Puan (Öğenin } \\
\text { ağırlık puanı) }\end{array}$ \\
\hline Peyzaj Değeri & $P$ & 35 \\
\hline İklim Değeri & $\mathrm{i}$ & 25 \\
\hline Ulaşılabilirlik & $U$ & 20 \\
\hline Rekreatif Kolaylık & RK & 20 \\
\hline Olumsuz Etkenler & OSE & (Minimum -10) \\
\hline $\begin{array}{l}\text { Rekreasyon } \\
\text { Potansiyeli (\%) }\end{array}$ & \%RP & 100 \\
\hline
\end{tabular}

Gülez yönteminde belirlenen kriterlerin her birinin birden fazla öğesi bulunmaktadır. Bu öğeler ve öğelerin ağırık puanları Çizelge 2 'de belirtildiği gibidir. Belirtilen çizelgenin detaylı hali hazırlanmış ve katılımcılara değerlendirilmeleri için sunulmuştur.

Gülez yöntemine göre çalışma alanında tespit edilen rekreasyon potansiyeli toplam puanı "çok düşük ve çok yüksek" aralığında sınıflandırılmaktadır. Yüzdelik olarak belirlenen değerler ve bu değerlerin karşılığı Çizelge 3'de belirtildiği gibidir.

\section{İstatistiksel Değerlendirme}

Uzman görüşlerine dayalı olarak uygulanan anketlerden elde edilen veriler bir istatistiksel değerlendirme programı olan IBM SPSS Statistics 20 programına aktarılmıştır. Ankete verilen yanıtlar arasındaki ilişkileri analiz etmek amacıyla "Ki-Kare Testi" yapılmıştır. Bu analizini gerçekleştirmenin temel amacı ise, yöntemde 
bulunan Ulaşılabilirlik (U) ve Rekreatik Kolaylık (RK) kriterlerinin Olumsuz Etkenler (OSE) kriteri üzerindeki etkisini tespit etmektir. Burada iki ana kriterin hedef alınmasının sebebi, değişken olmasından dolayıdır. Peyzaj Değeri ve İklim Değeri doğal öğeleri, değişmesi insan aracılığıyla mümkün olmayan veya kısmen değişime açık kriterlerdir. $\mathrm{Bu}$ nedenle alanın rekreasyonel potansiyelinin artırılması için insan etkisi ile değişimin kolaylıkla gerçekleştirilebileceği varsayımıyla U, RK ve OSE kriterleri hedef alınmıştır.

Çizelge 2. Gülez yöntemi öğeleri ve öğelerin ağırlık puanları (Gülez 1990)

\begin{tabular}{|c|c|c|}
\hline Öğeler & Öğenin Özellikleri & $\begin{array}{lr}\text { Maksimum } & \text { Puan } \\
\text { (Öğenin ağırlık puanı) }\end{array}$ \\
\hline \multirow{6}{*}{$\begin{array}{l}\text { Peyzaj } \\
\text { Değeri (P) }\end{array}$} & Alanın Büyüklüğü & 4 \\
\hline & Bitki Örtüsü & 8 \\
\hline & Deniz, göl, akarsular & 8 \\
\hline & Yüzeysel Durum & 5 \\
\hline & Görsel Kalite & 4 \\
\hline & Diğer Özellikler & 6 \\
\hline \multirow{4}{*}{$\begin{array}{l}\text { İklim Değeri } \\
\text { (i) }\end{array}$} & Sıcaklık & 10 \\
\hline & Yağış & 8 \\
\hline & Güneşlenme & 5 \\
\hline & Rüzgârlılık & 2 \\
\hline \multirow{4}{*}{$\begin{array}{l}\text { Ulaşılabilirlik } \\
\text { (U) }\end{array}$} & $\begin{array}{l}\text { Bulunduğu bölgenin } \\
\text { Turistik önemi } \\
\text { Bulunduğu bölgenin en } \\
\text { az } 100.000 \text { nüfuslu kent } \\
\text { olması }\end{array}$ & 5 \\
\hline & Ulaşılan zaman süresi & 4 \\
\hline & $\begin{array}{l}\text { Ulaşım ( taksi ve özel oto } \\
\text { dışında ) }\end{array}$ & 4 \\
\hline & Ulaşımda diğer kolaylıklar & 3 \\
\hline \multirow{8}{*}{$\begin{array}{l}\text { Rekreatif } \\
\text { Kolaylık (RK) }\end{array}$} & $\begin{array}{l}\text { Piknik tesisleri } \\
4\end{array}$ & \\
\hline & Su durumu & 3 \\
\hline & Geceleme tesisleri & 2 \\
\hline & Tuvaletler & 2 \\
\hline & Otopark & 2 \\
\hline & Kır gazinosu, satış büfesi & 2 \\
\hline & Bekçi ve görevliler & 2 \\
\hline & Diğer kolaylıklar & 3 \\
\hline \multirow{6}{*}{$\begin{array}{l}\text { Olumsuz } \\
\text { Etkenler } \\
\text { (OSE) }\end{array}$} & Hava kirliliği & -3 \\
\hline & Güvenceli olmaması & -2 \\
\hline & Su kirliliği & -1 \\
\hline & Bakımsızlık & -1 \\
\hline & Gürültü & -1 \\
\hline & Diğer olumsuz etkenler & -2 \\
\hline
\end{tabular}

Rekreasyon Potansiyeli Toplamı (\%RP)
Çizelge 3. Orman içi rekreasyon potansiyeli değerleri (Gülez 1980)

\begin{tabular}{cc}
\hline Orman içi rekreasyon potansiyeli & Sınıflama değerleri \\
\hline Çok düşük & $\% 30^{\prime}$ dan aşağı \\
Düşük & $\% 30-\% 45$ \\
Orta & $\% 46-\% 60$ \\
Yüksek & $\% 61-\% 75$ \\
Çok yüksek & $\% 75^{\prime}$ den yukarı \\
\hline
\end{tabular}

\section{BULGULAR ve TARTIŞMA}

Gülez (1990) yöntemine göre hazırlanan ve 17 öğretim elemanının katılım sağladığı anket verilerinin analizinde, Harbiye Şelalesi mesire alanının rekreasyon potansiyelini oluşturan temel öğelere göre detaylı değerlendirilmesi aşağıda özetlenmiştir.

\section{Peyzaj Değeri (PD)}

Mesire alanında çalışma alanı sınırları dâhilinde toplam büyüklük 60.7 ha.'dır. Bitki örtüsü ağaçlık, çalılık ve çayırlıktır. Mesire alanı şelale çevresinde sınırlandırılmıştır. Oldukça engebeli, dik bir topoğrafyaya sahiptir. Alanın birçok noktası güzel görüş ve vistaya olanak tanımaktadır. Peyzaj değeri taşıyan diğer özellikleri ise, efsanevi öyküleri, ipek ticaretinin yapılması ve bu nedenle turistik öneme sahip olması, şehir merkezine yakın fakat insan yoğunluğunun az olduğu bir konumda bulunması, doğası nedeniyle mikro klima etkisi yaratması, şehir merkezine oranla yaz aylarında daha serin olduğundan halkın talebinin yoğun olduğu bir yerdir.

\section{İklim Değeri (ID)}

Mesire alanının yaz ayları (haziran, temmuz, ağustos) ortalama sıcaklığı $25^{\circ} \mathrm{C}$ iken, belirtilen aylarda ortalama yağıs $66.2 \mathrm{~mm}$ 'dir (Anonim 1). Yaz aylarında bulutluluk ortalaması ise 0-2 gün, ortalama rüzgâr hızı ise 1-3 m/sec aralığında değişmektedir.

\section{Ulaşılabilirlik (U)}

Mesire alanı Samandağ, Yayladağı, Altınözü ilçeleri ile Lazkiye (Suriye) karayolu güzergâhında bulunmaktadır. Antakya merkez ilçesine $10 \mathrm{~km}$. uzaklıktadır. Yakın çevrede bulunan ilçelere taşıtla ortalama 0-30 dk. arasında ulaşım sağlanmaktadır. Alana özel araç, otobüs ve dolmuşlarla ulaşılabilmektedir. 


\section{Rekreatik Kolaylık (RK)}

Çalışma kapsamında gerçekleştirilen uzman görüşleri ile saha çalışmasında elde edilen verilere göre mesire alanında rekreatif kolaylık sağlayacak mevcut materyaller belirlenmiştir. Bu kapsamda, belediyeye ait 20 adet satış birimi (hediyelik eşya için), 2'si belediyeye ait 16 adet restoran, özel işletmeye ait 2 adet otopark ile 1 adet tuvalet ve belediyeye ait 5 adet çöp konteynerı bulunmaktadır. Mesire alanında belediyeye ya da özel işletmelere ait bekçi/güvenlik bulunmamaktadır. Ayrıca özel işletmeleri kullanmak istemeyenler için herhangi bir otopark, oturma birimi, çeşme, piknik tesisleri ve çocuk oyun alanları bulunmamaktadır. Alanda dağınık halde çöp konteynerları bulunurken, yol güzergâhlarında çöp kovaları ile banklar mevcut değildir. Bununla birlikte gece kullanılan aydınlatmalar yetersizdir. Ayrıca alan içi yönlendirme levhaları sınırlı sayıdadır. Şekil 3'de gösterildiği gibi alan içerisindeki yollar toprak yoldur ve genel itibariyle eğim \%15'un üzerindedir. Belirtilen fiziksel koşullar nedeniyle mesire alanı, engelli insanların kullanımı için elverişli değildir.

\section{Olumsuz Etkenler (OSE)}

Ankete katılım sağlayan uzmanların $\% 52.9^{\prime}$ u mesire alanında "gözlenebilir seviyede" hava kirliliğinin olduğunu, \%64.7'si ise su kirliliğinin olduğunu belirtmişlerdir. \%64.7'si mesire alanını "güvenli bulmazken", \%94.1'i ise alanı "bakımsı" olarak değerlendirmişlerdir. Ek olarak katılımcıların \%82.4'ü alanda rahatsız edici yoğunlukta gürültünün olduğunu belirtmişlerdir. Ayrıca katılımcılar mesire alanının, doğal yapısının bozulduğunu, işletmelerin hizmet kalitesinin düşük, piknik alanı, çöp toplama alanı, tuvalet ve oturma birimlerinin kullanıcı yoğunluğuna oranla yetersiz ve yürüme-araç yollarının aşınmış olduğunu dile getirmişlerdir.

Anket verilerinin değerlendirmesinde öğelerin aldığı puanlar sırasıyla peyzaj değeri (\%24), iklim değeri (\%24), ulaşılabilirlik (\%16), rekreatif kolaylık (\%10) ve olumsuz etkenler (\%9)dur. Formül kapsamında olumsuz etkenler negatif etkiye sahip olduğundan dolayı toplam puandan çıkartılmıştır. Anket verilerinin değerlendirilmesi ve formülize edilmesi sonucunda Harbiye Şelalesi mesire alanının toplam rekreasyon potansiyeli \%65 olarak belirlenmiştir. Bu oranla Çizelge 3'de verilen değerler kapsamında mesire alanı, Gülez (1980) yöntemine göre nitelik bakımından "rekreasyon potansiyeli yüksek" bir alandır. Gülez (1980) yöntemine göre orman içi rekreasyon alanlarının potansiyelini belirlemede alacakları maksimum puan ve Harbiye Şelalesi mesire alanının aldığı puan Çizelge 4'de sınıflandırılmıştır.

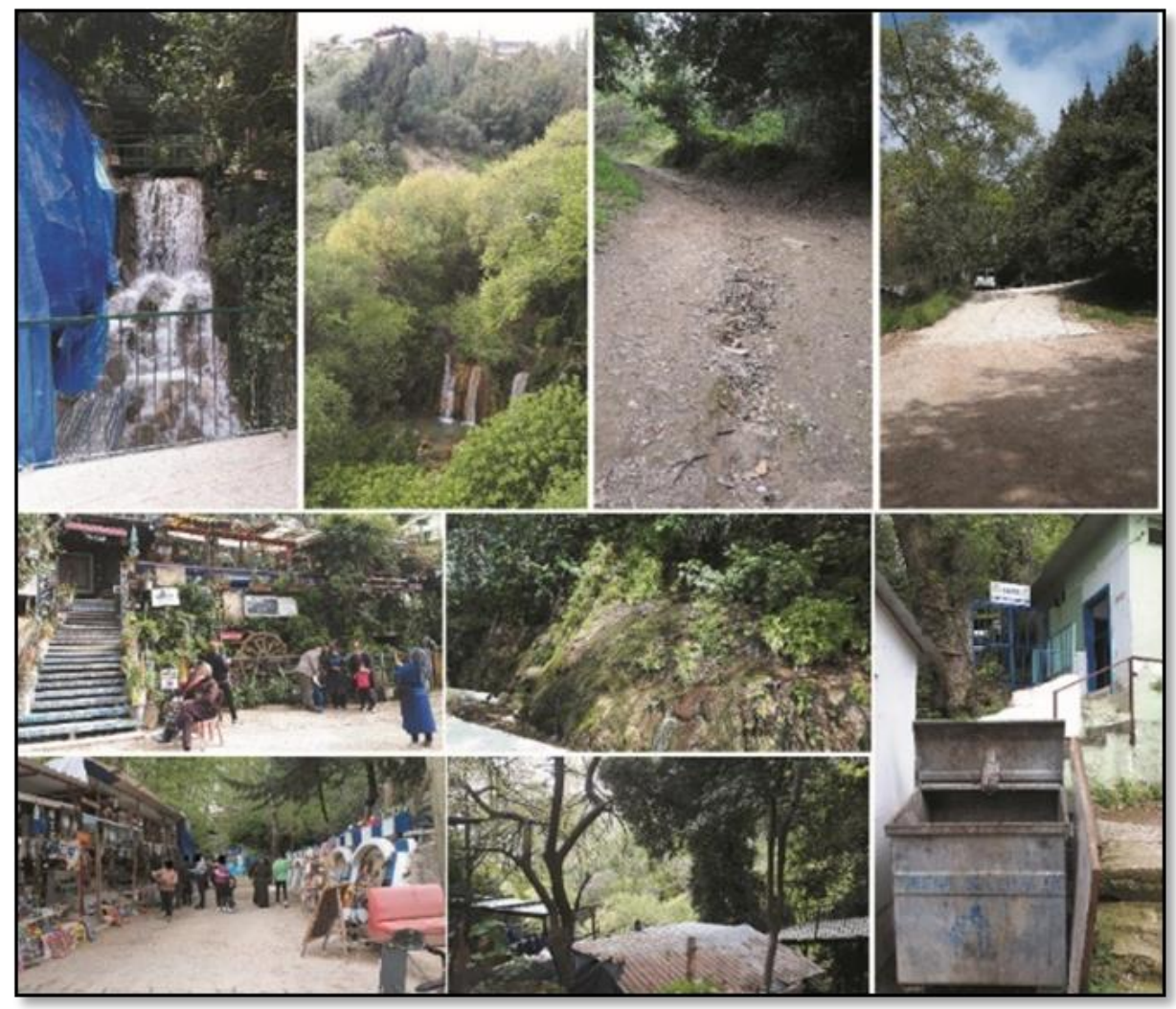

Şekil 3. Harbiye Şelalesi mesire alanından görüntüler (Orijinal, 2021) 
Çizelge 4. Gülez yöntemine göre çalışma alanının toplam rekreasyon potansiyel

\begin{tabular}{ccccccc} 
& Peyzaj Değeri & iklim Değeri & Ulaşılabilirlik & $\begin{array}{c}\text { Rekreatif } \\
\text { Kolaylıklar }\end{array}$ & $\begin{array}{c}\text { Olumsuz } \\
\text { Etkenler }\end{array}$ & $\begin{array}{c}\text { Toplam Puan } \\
\text { Maksimum Puan }\end{array}$ \\
\hline Aldığı Puan & 35 & 25 & 20 & 20 & -10 & 100 \\
\hline & 24 & 24 & 16 & 10 & -9 & 65
\end{tabular}

\section{Anket Sonuçlarının İstatistiksel Analizi}

Gülez yöntemine göre yapılan anketin sonucunda elde edilen Ulaşılabilirlik (U) ve Rekreatik Kolaylık (RK) kriterlerinin, Olumsuz Etkenler (OSE) kriterleri üzerindeki etkisi, IBM SPSS Statistics 20 yazılımında değerlendirilmiştir.

Anket sonucunda yazılıma aktarılan veriler nicel verilerdir ve bu nedenle parametrik testler uygulanmıştır. Parametrik testin uygulanabilirliği için verilerin (1) normal dağııımı ve (2) varyansların homojen olması gerektiğinden "Test of Normality" ve "Test of Homogeneity of Variances" testleri yapılmıştır. Sonuç olarak verilerin normal dağılım gösterdiği ve varyansların homojen dağıldığı tespit edilmiştir.

Bir alanın rekreasyon potansiyelini en yüksek oranda (\%35) peyzaj değeri etkilemektedir. Fakat Çizelge 4'de gösterildiği gibi bu çalışma alanının peyzaj değeri düşük (\%24) olarak saptanmıştır. Anket verileri incelendiğinde, alanın akarsu kıyısında konumlanmış olması, orta engebeli/sarp ile belirtilen yüzeysel durumu ve puanlaması kısmen düşük olan güzel görüş/vistalara sahip olması peyzaj değerini düşüren sebepler olarak değerlendirilmiştir.

Gülez (1990) yöntemine göre belirlenen kriterlerden peyzaj değerindeki öğeler mesire alanında yapılacak revize çalışmaları ile değişmesi kısmen, iklim değerindeki öğeler ise değişmesi mümkün olmayan öğelerdir. Ulaşılabilirlik, rekreatif kolaylık ve olumsuz etkenler, zamanla olumlu/olumsuz değişim sağlayabilecek kriterlerdir.

SPSS 20 yazılımında analiz edilmek üzere iki ayrı hipotez oluşturulmuş ve öğelere "Ki-Kare Testi" uygulanmıştır. H1 hipotezlerinin doğrulanması durumunda ise, etki düzeylerini belirlemek için "Gamma (kriterlerin ordinalordinal olmasından dolayı) testi" yapılmıştır. Etki düzeyleri için geleneksel olarak 0.33 altındaki ilişkiler zayıf, 0.34-0.60 arasındaki ilişkiler orta, 0.61 üzerindeki ilişkiler ise güçlü olarak kabul edilir (RTÜK 2009).
Ho1; Ulaşılabilirlik kriterinin olumsuz etkenler kriteri üzerinde bir etkisi yoktur.

H11; Ulaşılabilirlik kriterinin olumsuz etkenler kriteri üzerinde bir etkisi vardır.

Ho2; Rekreatif kolaylık kriterinin olumsuz etkenler kriteri üzerinde bir etkisi yoktur.

H12; Rekreatif kolaylık kriterinin olumsuz etkenler kriteri üzerinde bir etkisi vardır.

Ki-Kare testi ile elde edilen veriler \%95 güven aralığı ve \%5 hata payı ile analiz edilmiştir. Analiz sonucunda, ulaşılabilirlik-olumsuz etkenler kriterleri arasındaki ilişkide Ho1 hipotezi doğrulanırken, rekreatif kolaylıkolumsuz etkenler kriterleri arasındaki ilişkide ise H12 hipotezi doğrulanmıştır.

H12 hipotezinden elde edilen bulgulara göre, (i) piknik tesisleri ile hava kirliliği arasındaki değer 0.692 pozitif yönde ve (ii) geceleme tesisleri ile mesire alanının güvenceli olmaması öğeleri arasındaki değer -1.000 negatif yönde güçlü bir ilişki belirlenmiştir. Ayrıca (iii) tuvalet durumu ile güvenceli olmaması öğeleri arasındaki değer ise 0.818 olduğundan pozitif yönde güçlü bir ilişki saptanmıştır (Çizelge 5).

Gülez yöntemi birçok araştırmacı tarafından (Şimşek ve Korkut 2009, Yılmaz ve ark. 2009, Polat ve Aktaş Polat 2016, Surat 2017, Sü Eröz ve Aslan 2017, Gül ve Yılmaz 2019, Özçalık ve Kumru 2019, Çetinkale Demirkan ve Sandal Erzurumlu 2020, Tülek 2021) "Rekreasyon Potansiyeli Belirleme Yöntemi" olarak kullanılmıştır. Belirtilen çalışmalarda denek, yazarın kendisi ya da alan kullanıcıları şeklinde oluşturulmuştur. Ayrıca çalışma alanlarının toplam rekreasyon potansiyelleri çoğunlukla yüksek ve çok yüksek olarak belirlenmiştir. Ek olarak birkaç çalışmaya (Yılmaz ve ark. 2009, Çetinkale Demirkan ve Sandal Erzurumlu 2020) Gülez yöntemini destekleyici şekilde istatistiksel analizler uygulamıştır. Her iki çalışmada da Gülez yöntemi kriterlerinin birbirleri ile ilişkilerinin saptanması amaçlanmıştır. Analiz sonuçlarında peyzaj değeri kriterinin toplam rekreasyon 
potansiyeli üzerinde güçlü etkisi olduğu sonuçlarına varılmıştır.

Çizelge 5. H12 hipotezinin ilişkili öğelerinin istatistiksel etki düzeyleri

\begin{tabular}{lll}
\hline Symmetric Measures & & \\
\hline Piknik tesisleri-Hava kirliliği & Value & Approx. Sig. \\
Ordinal by Ordinal “Gamma” & .692 & .013 \\
N of Valid Cases & 17 & \\
Tuvalet durumu- Güvenceli olmaması & Value & Approx. Sig. \\
Ordinal by Ordinal “Gamma” & -.818 & .013 \\
N of Valid Cases & 17 & \\
Geceleme tesisleri-Güvenceli olmaması & Value & Approx. Sig. \\
Ordinal by Ordinal “Gamma” & -1.000 & .019 \\
N of Valid Cases & 17 & \\
\hline
\end{tabular}

Gülez yöntemine göre yapılmış olan örnek çalışmalar incelendiğinde, bu çalışma literatürdeki istatistiksel alt yapıya katkı sunmaktadır. Bu analiz şekliyle daha önce dikkate alınmayan ve çalışma sonucunu önemli derecede etkileyen "rekreatif kolaylık ve olumsuz etkenler" kriterleri analiz edilmiştir. Bu nedenle bu çalışma ile istatistiksel katkı ve uzman görüşlerinin alınması ile literatüre farklı bir boyut kazandırmak hedeflemiştir. Ayrıca önceki çalışmaların kapsamına bakıldığında, denekler değişkenlik göstermektedir. Bu kapsamda ilerleyen dönemlerde denek olarak mesire alanı kullanıcıları seçilebilir. Böylelikle çalışmanın farklı kullanııı profilinden doğrulaması sağlanabilir. İlerleyen çalışmalarda Gülez yöntemi kapsamında yapılacak ek istatistiksel yöntemler ve elde edilen bulgular, rekreasyon potansiyelini artırmada etkili bir veri sunabilir.

\section{SONUÇ ve ÖNERILER}

Doğal öğeler (peyzaj değeri, iklim değeri) insan etkisiyle değişmesi mümkün olmayan veya kısmen değişebilecek öğelerdir. Fakat çalışma kapsamında da belirtildiği ve analiz edildiği gibi kültürel öğeler (ulaşılabilirlik, rekreatif kolaylık) değişime açık öğelerdir ve burada insan etkisi önemlidir. Bu nedenle kültürel öğeler üzerindeki iyileştirme ya da talep ve standartlara uygun düzenleme ile rekreasyon potansiyeli artırılabilir. Rekreasyon potansiyeli belirlenecek alanda mevcut olumsuz etkenleri değerlendirmeye almak bir gerekliliktir (Gülez 1980). Bu bağlamda olumsuz etkenlerin en aza indirgenmesi de alan üzerindeki eksikliği azaltacaktır. Burada önemli olan kültürel öğelerin analizidir. Bu nedenle ulaşılabilirlik ve rekreatif kolaylık kriterlerinin olumsuz etkenler kriteri üzerindeki etkisi önemlidir. Çünkü değişime açıktır.

İstatistiksel analiz sonucunda ulaşılabilirlik kriterinin olumsuz etkenler kriteri üzerinde bir etkisi bulunamamıştır. Rekreatif kolaylık kriterinin ise olumsuz etkenler kriteri üzerinde anlamlı ve güçlü etkileri olduğu saptanmıştır. (i) piknik tesislerinin sayısının artırılması hava kirliliğini de artırmaktadır. Burada önemli olan kullanıcı tipleridir. Bu nedenle piknik tesislerinin hava kirliliğini önleyici tasarım yaklaşımlarıyla giderilmesi gerekmektedir. Aksi halde mevcutta gözlenen hava kirliliği oranı artabilir. (ii) geceleme tesislerinin fazla olması güvenirliliği artıran bir etki olarak belirlenmiştir. Bu nedenle kullanıcı sayısı ile doğru orantılı şekilde geceleme tesisleri oluşturulabilir. (iii) ayrıca mesire alanındaki tuvalet sayısının fazla olması o alanda daha güvenli hissedilmesini sağlamıştır. Çünkü kullanıcının bulunduğu bölgenin dışına çıkmadan ihtiyaçlarını o alandan karşılaması, güven duygusunun güçlenmesine neden olabilir. Belirtilen üç ilişkinin özünde "kullanıcı tipi, kullanıc sayısı ve kullanıcı duygusu" barınmaktadır.

Harbiye Şelalesi mesire alanı \%65 ile "rekreasyon potansiyeli yüksek" alan olarak belirlenmiştir. Fakat uzmanların görüşleri ve alanda yapılan analizler ile mesire alanının oldukça bakımsız, donatı elemanlarının yetersiz, güvenli olmayan, tuvalet, otopark ve geceleme tesislerinin kullanıc sayısına oranla yetersiz veya yoksun olduğu sonucuna ulaşılmıştır. Bu nedenle mesire alanı, ziyaretçilerin intiyaçlarını karşılayabilecek nitelik ve nicelikte olmadığı görülmektedir. Tüm bu olumsuz faktörler ile mesire alanı rekreasyon potansiyeli yüksek olması alanın doğal öğelerinin (peyzaj değeri, iklim değeri) değerlerinin yüksek olmasından kaynaklıdır. Alanda rekreatif kolaylık ve olumsuz etkenler öğeleri üzerinde yapılacak düzenlemeler, mesire alanının rekreasyon potansiyelini yükseltilebilecektir.

Harbiye Şelalesi mesire alanını "rekreasyon potansiyeli çok yüksek" olarak belirlenmesi ve alandan etkin bir şekilde yararlanılması için aşağıdaki önerilerin geliştirilmesi gerekebilir:

-Hatay ili farklı medeniyetlere ev sahipliği yapmış mistik bir kenttir. Suriye sınırında bulunması, farklı dinlere sahip insanların bir arada yaşadığı medeniyetler şehri olarak bilinmesi, tarihi, sosyal ve kültürel özellikleri yerli ve yabancı turistlerin alanı ziyaret etmesine neden olmaktadır. Harbiye Şelalesi ise il genelinde bulunan 3 şelaleden biri (Anonim 2) olması nedeniyle niteliksel olarak özel bir yerdir. Bu nedenle koruma-kullanma ilkeleri ile cazibe merkezi haline dönüştürülebilecek bir alandır.

-Mesire alanında yöresel hediyelik eşyaların satıldığı satış birimleri mevcut iken, ziyaretçilerin ayaküstü yeme-içme 
intiyaçlarını karşılayabilecek satış birimleri bulunmamaktadır. $\mathrm{Bu}$ nedenle satış büfeleri oluşturulmalıdır.

-Alanda ziyaretçilerin zorluk çekmeden araçlarını park edeceği şekilde standartlara ve ziyaretçi sayısına uygun otopark inşa edilmelidir.

-Kilit parke ve toprak yoldan oluşan yaya ve araç yollarında iyileştirmeler yapılmalıdır. Böylelikle alanın doğasına ve yapısına uygun olarak hem engelli hem de diğer insanların rahatlıkla kullanabileceği zemin döşemeleri seçilmelidir.

-Gündüzleri ve geceleri alanda bekçi, güvenlik bulunmamaktadır. Bu durum mesire alanını güvensiz hale getirmekte ve rekreasyon potansiyelini düşürmektedir. Ayrıca ziyaretçilerin kendilerini güvensiz hissetmelerine neden olmaktadır. Bunun sonucunda suç oranı ve alana verilen tahribatlar artabilir. Bu nedenle kullanıcıların yoğun olduğu hafta sonları ile hafta içi belirli saatlerde alanın güvenliğini sağlayacak görevliler bulunmalıdır.

-Alanda özel işletmeleri kullanmak istemeyen veya yalnızca rekreasyon amaçlı kullanmak isteyen ziyaretçiler de bulunmaktadır. Bu ziyaretçilerin rekreatif ihtiyaçlarını karşılayacak tuvalet, oturma birimi (Neufert (1983)'e göre tasarlanan oturma birimleri, insanların anatomik yapısına uygun (ergonomik) ve konforlu olmalıdır), piknik tesisleri, çöp kovaları (genellikle yükseklikleri $60-100 \mathrm{~cm}$ arasında (Yörük ve ark. 2006)), çeşme, çocuk oyun alanları ve spor alanları ile yürüyüş, koşu ve bisiklet parkurları mevcut değildir. Ayrıca analiz sonuçlarında piknik tesisleri ile hava kirliliği arasında güçlü bir ilişki saptandığı için piknik tesislerinin hava kirliliğine sebebiyet vermeden tasarlanması gerekebilir. Alandaki bu intiyaçların planlama ve tasarım ilkeleri doğrultusunda karşılanması rekreasyon potansiyelini artırmada önemli etkendir.

-Yeterli yönlendirme tabelaları ile alan içindeki koordinasyon sağlanmış olacaktır. Yönlendirme tabelaları ortalama bir mesafeden görülmeli, yayalar ve otomobiller için tehlike yaratacak alanlarda konumlandırılmamalıdır (Uzun 2002).

-Mesire alanı kent merkezine yakın konumda ve mikroklima etkisi yaratan doğası nedeniyle sportif rekreasyon aktivitelerinin yapılabileceği bir alandır. Dolayısıyla sportif aktivitelerin yapılacağı alanlar oluşturulmalıdır.
-Yılın belirli ayları veya günlerinde alanda etkinlikler düzenlenebilir. Böylece mesire alanında ziyaretçi sayısı artarak cazibe merkezi haline getirilebilir.

-Yol genişlikleri çalışılan alanın konumu, kullanıcı yoğunluğu ve kullanım sıklığına göre tasarlanmalıdır. Ayrıca kullanım amacına göre yolun malzemesi seçilmelidir. Bu malzemelerde oluşabilecek çukur, tümsek, kırık vb. hatalar yayaları yürürken rahatsız eder. Ayrıca çukur ve kırıkların arası yağmurdan sonra yağmur suyuyla dolarak çamurlaşmaya neden olabilir (Yörük ve ark. 2006). Alanda altyapının düzgün olmaması ve uygun malzeme kullanılmaması nedeniyle yağmur suyunun bir kısmı drene edilemeden birikmektedir. Yapılacak altyapı çalışmaları ve uygun malzeme seçimi ile düz zeminlerdeki birikimin ve doğrudan çamurlaşmanın önüne geçilebilecektir.

-Alanda gözlenebilir seviyede hava kirliliği bulunmaktadır. Bunun nedeni olarak karayolu güzergâhında bulunan taşıtlardan gelen kirlilik ile civar semtlerdeki evlerde sobalarda yakılan kömür ve piknik tesislerinden çıkan duman gösterilebilir. Bunun sonucunda yalnızca taşıt kirliliğine müdahale edilebilmesi mümkündür. Burada özellikle bitki ile yapılacak perdeleme sonucunda ana yoldan gelen gürültü ve kirlilik azaltılmış olacaktır. Çevreleme elemanları dar alanlarda $15-20 \mathrm{~cm}$ genişliğinde, geniş alanlarda ise 2-3 m genişliğinde bir bitkilendirme perdesi olarak planlanabilir (Uzun 2000).

-Alandaki zengin bitki örtüsü ve 2 farklı noktada bulunan şelale kaynağı ile hâkim manzaralara sahip seyir noktaları oluşturulabilir.

-Mesire alanı doğası nedeniyle gezinti işlevini yerine getirebilecek potansiyelde bir yerdir. Bu nedenle alan içerisinde ziyaretçilerin güvenliği sağlanarak yürüyüş rotası oluşturulmalıdır.

-Dış mekânlarda uygulanacak rampaların eğimi en fazla \%20 olmalıdır. \%15'i geçen rampa eğimlerinde yürüme zorlaşır. Bu nedenle sahanlıklar belirli aralıklarla yapılmalıdır (Uzun 2000, Yörük ve ark. 2006). Çalışma alanında çoğu yerlerde alan eğiminin \%15'in üzerinde olması alanı güvenlik açısından riskli yapabilmektedir. Bu nedenle fazla eğimin olduğu alanlarda sahan veya merdivenlerin oluşturulması alan içinde daha rahat ulaşımın sağlanmasını beraberinde getirebilecektir.

-Mesire alanındaki alt ve üst yapı yeniden düzenlenmelidir. Ayrıca ortamın yapısına uygun olarak rekratif etkinlikler çeşitlendirilmelidir. 
-Alanda belirlenecek sözlü ve yazılı kurallar ile ziyaretçilerin alanı kirletmelerinin önüne geçilebilir.

-Tüm donatı elemanları bölgenin iklim özelliklerine ve tasarım kriterlerine uygun olarak bütüncül ve sürdürülebilir bakış açısıyla oluşturulmalıdır.

-Alanda geceleme tesisleri ile güvenceli olması arasında güçlü negatif bir ilişki saptanmıştır. Bu nedenle geceleme tesisleri artırılarak kullanıcıların kendilerini güvende hissetmeleri sağlanabilir. Alandaki tuvalet sayılarının artırıması da kullanıcıların güvende hissetmelerini sağlayabilecektir.

-Alandaki planlama, tasarım ve iyileştirme çalışmaları yerel halk ihtiyaçları, ilgili belediye ve yönetim aracıları ile bilimsel temelli çalışmaların katkılarıyla meydana getirilmelidir. Böylelikle estetik, fonksiyonel ve yönetsel mekânlar tasarlanabilecektir.

\section{KAYNAKLAR}

Alkan O (2020) Erzurum ili Uzundere İlçesinin sportif rekreasyon potansiyelinin belirlenmesi. Haliç Üniversitesi Lisansüstü Eğitim Enstitüsü Yüksek Lisans Tezi, İstanbul

Altuntaş A (2020) Siirt ili Tillo Tabiat Parkı'nın kullanıc memnuniyet açısından değerlendirilmesi. Avrupa Bilim ve Teknoloji Dergisi. Sayı 18, S. 359-367. DOI: 10.31590/ejosat.690258.

Anonim 1 URL erişim: https://tr.climatedata.org/asya/tuerkiye/hatay/defne-927257/

Anonim 2 Hatay Valiliği. URL erişim: http://hatay.gov.tr/selaleler

Anonim, 3 Mesire Yerleri Yönetmeliği. Resmi Gazete, Sayı: 28578. http://www.resmigazete.gov.tr/eskiler/2013/03/20130305-9.htm (Erişim tarihi: 15.08.2018)

Aran (1967) Tabiatı koruma ve peyzaj güzelliklerinin muhafazası bakımından milli parklarımızın önemi. Milli Parklar ve Tabiatın Korunması Cemiyeti Yayın No: 10, Ankara

Broadhurst R (2001) Managing Environments For Leisure And Recreation. New York: Routledge

Buchwald K vd (1973) Gutachten fu r einen Landschaflsrahmenplan. Bodensee Baden Wiirttemberg. E'ın Beitrag zur regionalen Entwicklung im Baden-Wurtlembergischen Bodenseegebiet. Ministerium fu $r$ Ernaehrung Landwirtschat und Umwelt Baden Wurttemberg, Stuttgart, $206 \mathrm{~s}$

Çetinkale Demirkan G, Sandal Erzurumlu G (2020) According to method of gulez determination of recreational potential of Niğde Atatürk city forest. Uluslararası Sosyal ve Beşeri Bilimler Araştırma Dergisi. ISSN:2459-1149. s: 986-995
Gül S, Yılmaz A (2019) Samsun şehri kıyı şeridinin rekreasyon potansiyelinin Gülez'in açık hava rekreasyon potansiyelinin değerlendirilmesi yöntemi ile belirlenmesi. Coğrafi Bilimler Dergisi. 17(2), 318-344

Gülez S (1980) Orman içi rekreasyon potansiyelinin saptanması için geliştirilen bir değerlendirme yöntemi. İstanbul Üniversitesi Orman Fakültesi Dergisi, İstanbul

Hazar A (2014) Rekreasyon ve Animasyon. Ankara: Detay Yayıncılık.

Kiemstedt $H$ (1967) Zur bevverlung der landschaft fu $r$ die erholung. evaluation zur landespflege. Sonderheft; 1, Verlag Eugen Ulmer, Stuttgart

Madrigal R (2006) Measuring the multidimensional nature of sporting event performance consumption. Journal Of Leisure Research, 58, 3, 267-268

Özçalık M, Kumru S N (2019) Kapıçam Tabiat Parkı'nın Gülez yöntemine göre rekreasyon potansiyelinin belirlenmesi. Turkish Journal of Forest Science. 3(2): 129-141

Öztürk, S (2005). Kastamonu-Bartın Küre Dağları Milli Parkının Rekreasyonel Kaynak Değerlerinin İrdelenmesi, Süleyman Demirel Üniversitesi Orman Fakültesi Dergisi. Sayı:2. Isparta.

Polat, S. ve Aktaş Polat, S. (2016). Rekreasyonel Tabiat Parklarının Korunan Alanlar Kapsamında İncelenmesi: Mersin İli Örneği. Social Sciences ISSN: 1308 7444. 11(2), 85-115.

RTÜK (2009) Televizyon izleme eğilimlerinin araştırılması - 2. $162 \mathrm{~s}$

Surat H (2017) Gülez yöntemine göre Deriner Baraj Gölü ve yakın çevresi rekreasyonel potansiyelinin değerlendirilmesi ve alan kullanım önerilerinin geliştirilmesi. KSÜ Doğa Bilimleri Dergisi 20(3), 247-257. DOI: 10.18016/ksudobil.289461

Sü Eröz S, Aslan E (2017) Istranca (Yıldız) ormanlarının rekreasyon potansiyelinin Gülez Metodu ile değerlendirilmesi. Kesit Akademi Dergisi. ISSN: 2149-9225. s. 83-107

Şimşek D S, Korkut A B (2009) Kıyı şeridi rekreasyon potansiyelinin belirlenmesinde bir yöntem uygulaması: Tekirdağ merkez ilçe örneği. Tekirdağ Ziraat Fakültesi Dergisi, 6(3): 315-327

Tabachnick, Fidell (2013) B.G. Tabachnick, L.S. fidell using multivariate statistics (sixth ed.) Pearson, Boston

Tülek B (2021) Determination of recreation potential with using Gülez Method in Çankırı Kadınçayırı Natural Park example. ISPEC Tarım Bilimleri Dergisi, 5(1): 227-234

Uzun G (2000) Peyzaj Konstrüksiyonu I, Ç. Ü. Zir. Fak. Genel Yayın No: 125, Ders Kitapları Yayın No: 37, Adana, $256 \mathrm{~s}$

Uzun G (2002) Peyzaj Konstrüksiyonu II, Ç. Ü. Zir. Fak. Genel Yayın No: 137, Ders Kitapları Yayın No: A-42, Adana, $296 \mathrm{~s}$

Yılmaz H, Karaşah B, Erdoğan Yüksel E (2009) Gülez yöntemine göre Kafkasör Kent ormanının rekreasyonel potansiyelinin değerlendirilmesi. Artvin Çoruh Üniversitesi Orman Fakültesi Dergisi, 10(1): 53-61. ISSN: 1300-6053

Yörük I, Gülgün B, Sayman M, Ünal Ankaya F (2006) Peyzaj planlama çalışmaları kapsamında Ege Üniversitesi kampüs örneğindeki peyzaj donatı elemanlarının ergonomik-antropometrik açıdan irdelenmesi. Ege Üniversitesi Ziraat Fakültesi Dergisi. ISSN 10188851. 43(1):157-168

SPSS (2013) IBM SPSS Statistics 20.0 for Windows. Armonk, NY 